\title{
RAMADAN EFFECT ON STOCK MARKETS ${ }^{*}$
}

\author{
BORSALARDA RAMAZAN ETKİSİ
}

\section{Ömer Faruk TAN ${ }^{*}$ Şirin ÖZLEM ${ }^{* * *}$}

\begin{abstract}
The month of Ramadan is one the most renowned religious rituals in the world for more than 1.5 billion Muslims. This study analyzes the effect of religious experience during the Muslim holy days of Ramadan on the stock exchanges of 16 Muslim-majority countries. According to the results, among 16 countries, 13 Muslim financial markets have positive returns during Ramadan, which can be attributed to the generally positive investor mood or emotion. In contrast, only 4 stock markets-Dubai Financial Market, Amman Stock Exchange, Karachi Stock Exchange, and Tunis Stock Exchange-exhibit differences that are both positive and statistically significant. Moreover, the study divides the Muslim holy days into 3 periods, where the first period comprises the first 10 days of Ramadan, second period covers the next 10 days of the Ramadan month, and the final period involves the last 10 days. According to results, while the first 10 days witness the lowest performance, the last 10 days experience the highest performance.
\end{abstract}

Keywords: Ramadan Effect, Regression Analysis, Muslim Countries, Stock Markets

Öz

Ramazan ayı, dünyadaki 1,5 milyardan fazla Müslüman için en önemli dinsel ritüellerden biridir. $\mathrm{Bu}$ çalışma Ramazan ayının Müslümanların çoğunlukta olduğu 16 ülkenin menkul kıymetler borsası üzerindeki etkisini incelemektedir. Elde edilen sonuçlara göre, Ramazan ayının söz konusu 16 Müslüman ülkenin 13’ünde finans piyasası üzerinde olumlu etkisi görülmektedir ve bu etki genellikle pozitif yatırımcı ruh hali veya duygusu ile açıklanabilmektedir. Diğer taraftan, sadece Dubai, Ürdün, Pakistan ve Tunus Borsaları hem olumlu hem de istatistiksel olarak anlamlı farklılıklar göstermektedir. Ek olarak bu çalışma, Ramazan ayını; ilk on günü birinci dönem, ikinci on günü ikinci dönem ve son on günü üçüncü dönem olmak üzere üçe bölmüştür. Elde edilen sonuçlara göre, ilk on gün en düşük performans ile karşılaşılmakta, son on gün ise en yüksek performans gösterilmektedir.

Anahtar Kelimeler: Ramazan Etkisi, Regresyon Analizi, Müslüman Ülkeler, Borsalar

* This study is a version of the conference paper with the title "Regression Analysis of Stock Exchanges During the Ramadan Period: Analysis of 16 Countries" presented $4^{\text {th }}$. International Academic Conference on Social Sciences, International Institute for Academic Development, Barcelona, Spain, 28-29 July 2017.

** Research Assistant, Marmara University, Faculty of Business Administration, Department of Business Administration, omer.tan@marmara.edu.tr

*** Research Assistant, MEF University, Faculty of Engineering, Department of Industrial Engineering, ozlems@mef.edu.tr 


\section{Introduction}

Ramadan is the ninth month of the Muslim Hijri calendar and is the month in which the Quran was revealed to Prophet Mohammad. Muslims worldwide observe Ramadan as a month of fasting; it is mandatory for Muslims to do so and is one of Islam's five pillars. During the fast, Muslims cannot eat or drink anything from dawn until sunset (Al-Ississ, 2009). Further, Muslims are urged to refrain from wrongdoing (Husain, 1998) and are encouraged to devote themselves to acts of piety, prayers, and charity (Seyyed, 2005). Muslims are focused more on praying, reciting the Quran, and giving alms from their previous year's earnings. As a fundamental practice of the Islamic faith, Ramadan brings about a greater solidarity and collaboration between Muslims. Its main contribution is the greater social support that provides to the society as well as the close relationship an individual Muslim establishes with Allah (Białkowski, et. al, 2012).

Faith plays a very important function in decision-making and the actions of the people. Religious values and practices have an important effect on economic growth (Weber, 1930). According to a study on positive psychology, religion provides a valuable form of social support, inspires optimistic beliefs, and contributes to believers' happiness (Beit-Hallahmi \& Argyle, 1997). In Islamic countries, although the act of fasting during Ramadan means that Muslims spend the first half of the day feeling hungry, which expected to have a negative influence on investor mood, the contrary happens. According to religious beliefs, this is a holy month and investors generally feel better when they are trading during Ramadan (Al-Hajieh, 2011).

To mark the end of Ramadan, Muslims celebrate Eid-ul-Fitr (Ramadan Feast). Eid is the Arabic word for festivity and Eid-ul-Fitr means breakfast, so it symbolizes breaking of the fasting period. Eid-ul Fitr comprises the final three days of Ramadan. It is a time to celebrate the completion of a month of blessing and joy with family and friends (Al-Hajieh, 2011). In addition, there is also a sharp increase in prices especially in food, clothes, and commodities before the Eid celebration because people purchase them for the feast. After the celebration, prices revert to their original ones (Alrashidi, 2014). Most Islamic countries use both Gregorian and Islamic lunar calendars. The Islamic calendar is predominantly used for religious activities, whereas the Gregorian calendar is used for business and government purposes. According to the lunar calendar, Ramadan steps back each year in order to start about 10 days earlier. Thus, the month of Ramadan presents an opportunity to test and determine any predictable patterns in the behavior of stock returns and the volatility relative to other months of the year (Iqbal, 2013). Stock markets remain open during the Ramadan days that are observed by an overwhelming majority of the Muslim population. (Al-Ississ, 2015). First, this study tries to analyze the Ramadan effect on stock exchanges of 16 Muslim countries using a regression analysis method. Second, the Ramadan effect is analyzed in 3 segments, each consisting of 10 days of Ramadan month, in order to see whether investors display different attitudes during Ramadan. The remainder of this paper is organized as follows: Section 2 presents a literature review about this topic. Section 3 outlines the data and methodology. Section 4 discusses the empirical results, and Section 5 concludes this study. 


\section{Literature Review}

Husain (1998) explored the Ramadan effect on Karachi Stock Exchange covering the period from January 1989 to December 1993. The data consist of 36 individual stocks, 8 sector indices and the general market index. It can be concluded that the Ramadan does not significantly effect on the average return in the market; however, there is a strong evidence of a substantial decline in the volatility of stock returns. Frieder and Subrahmanyam (2004) analyzed the impact of the Christian holiday of St. Patrick's Day and the Jewish holy days of Rosh Hashanah and Yom Kippur on the U.S. equity markets over the 1946-2000 period. They found that stock returns were significantly higher on Rosh Hashanah but significantly lower on Yom Kippur days. For most holy days, trading volumes decline. Seyyed, Abraham, and Al-Haiji (2005) analyzed the Saudi Stock Exchange during the Ramadan periods. They analyzed different sector indices in the market. According to their finding, volatility and trading activity vanished significantly during Ramadan in Saudi Stock Exchange. Al-Ississ (2010) examined the effect of faith on the financial markets of 17 countries during the period between 1988 and 2008 . He found that Ramadan has a statistically significant positive effect on the returns of financial markets. On the other hand, Ramadan dropped the trading volume of financial markets.

Al-Hajieh, Redhead, and Rodgers (2011) investigated the Ramadan effect in Turkey, Jordan, Egypt, Kuwait, and Saudi Arabia during the period from January 1992 to December 2007. According to results, except for Saudi Arabia and Bahrain, average daily returns during Ramadan are both statistically significant and higher than the average returns of other months in the year. Furthermore, high volatility levels can be seen for all countries both at the beginning and end of the Ramadan. Białkowski, Etebari \& Wisniewski (2012) examined the 14 predominantly Muslim countries over the 1989-2007 period. Their results revealed that Ramadan stock returns are higher than other days but are less volatile compared to the rest of the year. No obvious declines in market liquidity can be observed during this festive season. Moreover, Ramadan has a positive impact on investors' mood and sentiment.

Ramezani, Pouraghajan, Mardani (2013) investigated the impact of lunar months on Tehran Stock Exchange during the period of 2002-2012. They found that there is a positive and significant relationship between Ramadan and Tehran stock exchange. Iqbal, Kouser and Azeem (2013) considered the Ramadan effect on Karachi Stock Exchange during the period of 1992 to 2011. The results indicate that there is a significant reduction in volatility of return, but the Ramadan effect is significant at 10\% level. Shah and Ahmed (2014) investigated the Ramadan effect in the context of the Karachi Stock Exchange between January 2010 and December 2012; they found that religion factors are not associated with financial markets, as the market remains the same during Ramadan as at any other month of the year. In accordance, they found that the Ramadan effect is not significant in the Karachi Stock Exchange. Alatiyat (2014) analyzed the 19 listed banks in Abu Dhabi Security Exchange (ADX) and Dubai Financial Market (DFM) during the periods of 2008 2013. The average returns for banks in ADX and DFM in Ramadan are less than the usual average in the period. The study also found that the Islamic banks stocks increase during the Ramadan period, thus it is profitable to buy those stocks before Ramadan and sell them in the Ramadan. 


\section{Methodology and Data}

This study estimates the impact of Ramadan on financial markets by running OLS regression analysis. Stock returns are analyzed using a logarithmic return. The advantage in looking at the $\log$ returns of a series is that one can see relative changes in the variable and compare these directly with other variables whose values may have very different base values. The following regression analysis is estimated to analyze the impact of faith on financial markets

$\mathrm{R}_{\mathrm{i}, \mathrm{t}, \mathrm{j}}=\beta_{0}+\beta_{1}$ Ramadan_Effect ${ }_{\mathrm{t}, \mathrm{j}}+{ }^{\varepsilon}{ }_{\mathrm{t}}$

where;

$\beta_{0}=$ regression intercept coefficient

$\beta_{1}=$ regression slope coefficient

$\mathrm{R}_{\mathrm{i}, \mathrm{t}, \mathrm{j}}=$ the logarithmic daily return of stock exchange (i) on day $(\mathrm{t})$ in country $(\mathrm{j})$

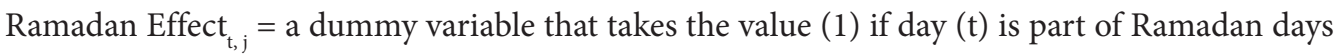
in country $(\mathrm{j})$ and $(0)$ otherwise

$\varepsilon_{\mathrm{t}}=$ Random error term

Moreover, the study divides Ramadan into three 10-day periods covering the 30-day period of Ramadan. This division is useful because although Ramadan is a continuous 29 or 30 days duration, the intensity of worship, features, and promised rewards vary.

"This a month (Ramadan), the first part of which brings Allah's Mercy, the middle of which brings Allah's forgiveness and the last part of which brings emancipation from hellfire" (Hadith in Sahih Al-Bukhari).

The first 10 days of Ramadan are the hardest ones because it is physically difficult to adjust to a new dietary schedule and nutritional deprivation during the day. Therefore, during the first 10day period, Ramadan is expected to be dominated by the physical impact of fasting rather than mystical experiences (Al-Ississ, 2010).

Moreover, the last 10 days of Ramadan are the most blessed part, as they include Laylat AlQadar-The Night of Decree is better than a thousand months-when the Quran was first revealed to the prophet Mohammad. The following regression analysis is computed to find whether differences exist between these three segments:

$\mathrm{R}_{\mathrm{i}, \mathrm{t}, \mathrm{j}}={ }^{\beta}{ }_{0}+{ }_{1}^{\beta}$ RamadanDays1_10 $0_{\mathrm{t}, \mathrm{j}}+{ }_{2}^{\beta}$ RamadanDays11_20 $0_{\mathrm{t}, \mathrm{j}}+{ }_{3}^{\beta}$ RamadanDays21_30 ${ }_{\mathrm{t}, \mathrm{j}}+{ }_{\mathrm{t}}^{\varepsilon}$

where 
$\mathrm{R}_{\mathrm{i}, \mathrm{j}, \mathrm{j}}=$ the logarithmic daily return of stock exchange $i$ on day $t$ from the trading day before in country $j$;

RamadanDays1_10 ${ }_{t, j}=$ a dummy variable that takes the value of 1 if day $t$ fall on days $1-10$ of Ramadan in country $j$;

RamadanDays11_20 ${ }_{\mathrm{t}, \mathrm{j}}=$ a dummy variable that takes the value of 1 if day $t$ fall on days 11-20 of Ramadan in country $j$; and

RamadanDays21_30 3 t $_{\mathrm{j}}=$ a dummy variable that takes the value of 1 if day $t$ fall on days $21-30$ of Ramadan in country $j$.

$\varepsilon_{\mathrm{t}}=$ Random error term

This study examines the stock exchanges of 16 countries to determine if a Ramadan effect could be observed in Table 1. All stock exchange data is obtained from the Thomson Reuters DataStream database. The time zone of the Indonesia Stock Exchange, Amman Stock Exchange, Dhaka Stock Exchange, Bursa Malaysia, Karachi Stock Exchange, and Borsa Istanbul have longer data ranging from January 1990 to August 2015. In contrast, data for Dubai Financial Market is available from January 2004 to August 2015. However, at least 10 years of Ramadan data is available for this stock exchange, and it is sufficient to include the sample in the study. Since data for Iran is not available with Thomson Reuters, Tehran Stock Exchange could not be included in this study. Also, instead of Abu Dhabi Stock Exchange, Dubai Financial Market's data is used for this study.

Table I. List of Stock Exchanges

\begin{tabular}{c|c|c|c|c}
\hline \multicolumn{1}{c}{ Country } & List of Stock Exchanges & \multicolumn{1}{c}{ Starting Date } & \multicolumn{1}{c}{ Ending Date } & Obs. Days \\
\hline Bahrain & Bahrain Stock Exchange & 02.01 .2003 & 31.08 .2015 & 3302 \\
Bangladesh & Dhaka Stock Exchange & 01.01 .1990 & 31.08 .2015 & 6695 \\
Abu Dhabi (Dubai) & Dubai Financial Market & 02.01 .2004 & 31.08 .2015 & 3042 \\
Egypt & Egyptian Exchange & 02.01 .1995 & 31.08 .2015 & 5390 \\
Indonesia & Jakarta Stock Exchange & 02.01 .1990 & 31.08 .2015 & 6695 \\
Jordan & Amman Stock Exchange & 02.01 .1990 & 31.08 .2015 & 6695 \\
Kuwait & Kuwait Stock Exchange & 03.01 .2000 & 31.08 .2015 & 4086 \\
Lebanon & Beirut Stock Exchange & 01.02 .1996 & 31.08 .2015 & 5108 \\
Malaysia & Bursa Malaysia & 02.01 .1990 & 31.08 .2015 & 6695 \\
Morocco & Casablanca Stock Exchange & 02.01 .2002 & 31.08 .2015 & 3563 \\
Oman & Muscat Securities Market & 01.11 .1996 & 31.08 .2015 & 4912 \\
Pakistan & Karachi Stock Exchange & 02.01 .1990 & 31.08 .2015 & 6695 \\
Qatar & Qatar Stock Exchange & 01.09 .1998 & 31.08 .2015 & 4436 \\
Saudi Arabia & Saudi Stock Exchange & 02.11 .1998 & 31.08 .2015 & 4392 \\
Tunisia & Tunis Stock Exchange & 02.01 .1998 & 31.08 .2015 & 4607 \\
Turkey & Borsa Istanbul & 02.01 .1990 & 31.08 .2015 & 6695 \\
\hline
\end{tabular}


Furthermore, countries are selected if the proportion of population professing the Muslim faith exceeded 50\%. Among these countries, Indonesia has the highest population of over 250 million people, whereas Bahrain has the lowest population of approximately 1.4 million people. In total, there are approximately 885 million Muslims living in these countries. According to the percentage of the Muslim population within the selected countries, while Saudi Arabia has the highest ratio with 100\%, Jordan has the lowest ratio with $54 \%$. Islam has two denominations: Sunni and Shia. Of the included countries, Bahrain has a mostly Shia population, and in Lebanon, the Shia and Sunni ratio is equal. Other countries mostly have a Sunni population. Islamic holy days follow the Hijri calendar, not Gregorian year, and the Muslim Hijri year is 11 days shorter than the Gregorian calendar year. Each Muslim country follows an independent and often different method to calculate the start of each lunar month. Countries can use astronomical calculations but differentiate between the required parameters. Hence, the first day of Ramadan varies from country to country in the same year. Due to these differences, starting date data is collected from different websites in order to determine the correct Ramadan start and end days for each country.

Table 2. Population of Muslim Majority Countries

\begin{tabular}{ccccc}
\hline Country & $\begin{array}{c}\text { Population (2014) } \\
\text { (million) }\end{array}$ & $\begin{array}{c}\text { Percent Muslim } \\
(\mathbf{\%})\end{array}$ & Denomination & $\begin{array}{c}\text { Share of World } \\
\text { Pop. }\end{array}$ \\
\hline Indonesia & $252.812,25$ & $87,20 \%$ & Sunni & $3,49 \%$ \\
Pakistan & $185.132,93$ & $96,40 \%$ & Sunni & $2,56 \%$ \\
Bangladesh & $158.512,57$ & $89,10 \%$ & Sunni & $2,19 \%$ \\
Egypt & $83.386,74$ & $90 \%$ & Sunni & $1,15 \%$ \\
Turkey & $75.837,02$ & $99,80 \%$ & Sunni & $1,05 \%$ \\
Morocco & $33.492,91$ & $99 \%$ & Sunni & $0,46 \%$ \\
Malaysia & $30.187,90$ & $61,30 \%$ & Sunni & $0,42 \%$ \\
Saudi Arabia & $29.369,43$ & $100 \%$ & Sunni & $0,41 \%$ \\
Tunisia & $11.116,90$ & $99,10 \%$ & Sunni & $0,15 \%$ \\
Jordan & $7.504,81$ & $97,20 \%$ & Sunni & $0,10 \%$ \\
Lebanon & $4.965,91$ & $54 \%$ & Sunni-Shia & $0,70 \%$ \\
Oman & $3.926,49$ & $85,90 \%$ & Sunni & $0,50 \%$ \\
Kuwait & $3.479,37$ & $76,70 \%$ & Sunni & $0,50 \%$ \\
United Arab & $2.327,00$ & $76 \%$ & Sunni & $0,32 \%$ \\
Emirates (Dubai) & $2.267,92$ & $77,50 \%$ & Sunni & $0,30 \%$ \\
Qatar & $1.344,11$ & $70,30 \%$ & Shia & $0,20 \%$ \\
Bahrain & 2 &
\end{tabular}

Source: http://www.worldometers.info/world-population/population-by-country/ and https://www.cia.gov/library/ publications/the-world-factbook/fields/2122.html 


\section{Empirical Results}

Figures 1, 2, and 3 (as seen in Appendix A) depict the time series evolution of the 16 different indexes considered in this study. Figure 1 shows the price index of the countries according to their time period of Ramadan observance. Figure 2 reports the daily returns of the respective stock exchanges excluding Ramadan days, and finally, Figure 3 presents stock returns on Ramadan days. Additionally, figure 3 provides a clear picture of the presence of volatility clusters.

Table 3 provides descriptive statistics of stock returns excluding Ramadan days. The average columns indicate stock market returns. Borsa Istanbul has the highest returns, whereas the Beirut Stock Exchange has the lowest returns. Except for Lebanon, all markets have positive returns in the duration of the study period. The standard deviation column indicates the stock market volatility. Qatar Stock Exchange has the highest range of maximum and minimum returns; it also has the highest standard deviation. The skew column displays the skew of stock markets. Except for Bursa Malaysia and Muscat Securities Markets, all examined stock markets have a negative skew. All stock markets have positive kurtosis, which implies typical heavy-tailed financial distributions.

Table 3. Descriptive Statistics of Excluding Ramadan Days

\begin{tabular}{ccccccc}
\hline Stock Exchanges & Mean & Std.dev. & Min & Max & Skew & Kurtosis \\
\hline Bahrain Stock Exchange & 0,0001 & 0,0057 & $-0,0492$ & 0,0361 & $-0,4467$ & 9,7848 \\
Dhaka Stock Exchange & 0,0003 & 0,0157 & $-0,2691$ & 0,1918 & $-1,0368$ & 47,7065 \\
Dubai Financial Market & 0,0002 & 0,0186 & $-0,1216$ & 0,122 & $-0,1336$ & 8,7125 \\
Egyptian Exchange & 0,0003 & 0,0147 & $-0,172$ & 0,1192 & $-0,4689$ & 12,1307 \\
Jakarta Stock Exchange & 0,0003 & 0,0145 & $-0,1095$ & 0,1313 & $-0,0669$ & 12,1369 \\
Amman Stock Exchange & 0,0002 & 0,0099 & $-0,2054$ & 0,1987 & $-0,1979$ & 66,098 \\
Kuwait Stock Exchange & 0,0003 & 0,0088 & $-0,0933$ & 0,063 & $-0,8822$ & 15,725 \\
Beirut Stock Exchange & $-0,0001$ & 0,0117 & $-0,3283$ & $-0,3283$ & $-4,5816$ & 143,2373 \\
Bursa Malaysia & 0,0002 & 0,013 & $-0,2415$ & 0,2082 & 0,3462 & 56,4978 \\
Casablanca Stock Exchange & 0,0003 & 0,0076 & $-0,0682$ & 0,0446 & $-0,5269$ & 10,0345 \\
Muscat Securities Market & 0,0002 & 0,011 & $-0,1484$ & 0,1986 & 0,3027 & 47,3722 \\
Karachi Stock Exchange & 0,0005 & 0,0146 & $-0,1321$ & 0,1276 & $-0,2501$ & 9,8208 \\
Qatar Stock Exchange & 0,0004 & 0,0256 & $-0,8581$ & 0,8447 & $-0,5314$ & 613,068 \\
Saudi Stock Exchange & 0,0004 & 0,015 & $-0,1168$ & 0,164 & $-0,6025$ & 16,7451 \\
Tunis Stock Exchange & 0,0003 & 0,0054 & $-0,05$ & 0,0462 & $-0,1033$ & 16,0194 \\
Borsa Istanbul & 0,0011 & 0,0253 & $-0,1998$ & 0,1564 & $-0,204$ & 7,3466 \\
\hline
\end{tabular}

Table 4 provides descriptive statistics of market returns only for Ramadan. Qatar Stock Exchange has the highest average during Ramadan, while Bursa Malaysia has the lowest returns. Dhaka Stock Exchange has the highest standard deviation, which is related to the range of maximum and minimum returns. While 6 markets have a positive skew, the other 10 have a negative skew. All markets have positive kurtosis, which indicate heavy-tailed financial distributions. During Ramadan days, stock market returns in Bahrain, Malaysia, Morocco, and Lebanon have negative average 
returns. However, market returns in Bangladesh, Dubai, Egypt, Pakistan, Jordan, Kuwait, Indonesia, Qatar, Saudi Arabia, Tunisia, and Turkey are higher during Ramadan compared with non-Ramadan months. The results indicate that Ramadan has a positive impact on stock prices. To the extent that it contributes to investors' positive mood and they might have a tendency to invest. If a person is in a good mood, he/she will have a tendency to be optimistic while evaluating an investment. Good moods may motivate investors to invest in risky financial instruments like stocks rather than bonds (Al-Hajieh, 2011). Nofsinger (2002) suggests an optimism bias. Optimistic thinking reduces critical analysis during the investment process and investors might ignore pessimistic information.

Table 4. Descriptive Statistics of Ramadan Days

\begin{tabular}{ccccccc}
\hline & Mean & Std.dev. & Min & Max & Skew & Kurtosis \\
\hline Bahrain Stock Exchange & $-0,0001$ & 0,0042 & $-0,0233$ & 0,0156 & $-1,1668$ & 9,3359 \\
Dhaka Stock Exchange & 0,0043 & 0,0828 & $-0,8652$ & 0,9341 & 3,3068 & 76,9408 \\
Dubai Financial Market & 0,0017 & 0,018 & $-0,1479$ & 0,0941 & $-1,7645$ & 23,7255 \\
Egyptian Exchange & 0,0011 & 0,0301 & $-0,1792$ & 0,5232 & 9,729 & 190,5292 \\
Jakarta Stock Exchange & 0,0002 & 0,0266 & $-0,5471$ & 0,1047 & $-14,3577$ & 298,5525 \\
Amman Stock Exchange & 0,0008 & 0,0103 & $-0,0973$ & 0,087 & $-0,6989$ & 40,663 \\
Kuwait Stock Exchange & 0,0009 & 0,01196 & $-0,05649$ & 0,19082 & 10,6948 & 177,8994 \\
Beirut Stock Exchange & $-0,0002$ & 0,0137 & $-0,2179$ & 0,0642 & $-8,0944$ & 137,6212 \\
Bursa Malaysia & $-0,0006$ & 0,0329 & $-0,7453$ & 0,1294 & $-18,9568$ & 434,7307 \\
Casablanca Stock Exchange & $-0,0002$ & 0,008 & $-0,0417$ & 0,0425 & $-0,203$ & 11,464 \\
Muscat Securities Market & 0,0001 & 0,0144 & $-0,2288$ & 0,0423 & $-9,7518$ & 152,6064 \\
Karachi Stock Exchange & 0,0036 & 0,0323 & $-0,0999$ & 0,7123 & 17,7363 & 383,9675 \\
Qatar Stock Exchange & 0,0059 & 0,0636 & $-0,478$ & 0,7746 & 4,9236 & 75,853 \\
Saudi Stock Exchange & 0,0004 & 0,0118 & $-0,0672$ & 0,0644 & $-0,9461$ & 12,2353 \\
Tunis Stock Exchange & 0,0008 & 0,0041 & $-0,0216$ & 0,021 & $-0,1311$ & 7,8807 \\
Borsa Istanbul & 0,003 & 0,0363 & $-0,1143$ & 0,4825 & 4,306 & 55,7791 \\
\hline
\end{tabular}

Table 5 provides the correlation of market returns excluding Ramadan days. Malaysia and Indonesia are the most correlated markets, which likely reflects their physical proximity, being neighbors, as well as on their financial integration. However, correlations between other countries are very low, so it can be concluded that there is scant financial integration among most Muslimmajority countries during non-Ramadan days. Morocco and Bahrain have the lowest correlation. Table 6 shows the correlation of market returns for Ramadan days. Malaysia and Indonesia are most correlated at 83.8\%. Also, the financial market of (1) Qatar and Bangladesh, (2) Indonesia and Morocco, and (3) Qatar and Dubai highly correlate with each other during Ramadan days. The comparison of Ramadan and non-Ramadan months reveals that correlations for Ramadan days are higher than other days. In Table 6, correlation results are mostly negative; however, correlations for Ramadan days are mostly positive, therefore it can be concluded that the financial markets of Muslim countries might move to the same trend during Ramadan as investors might have the same mood, i.e., happiness and optimism caused by Ramadan itself. 


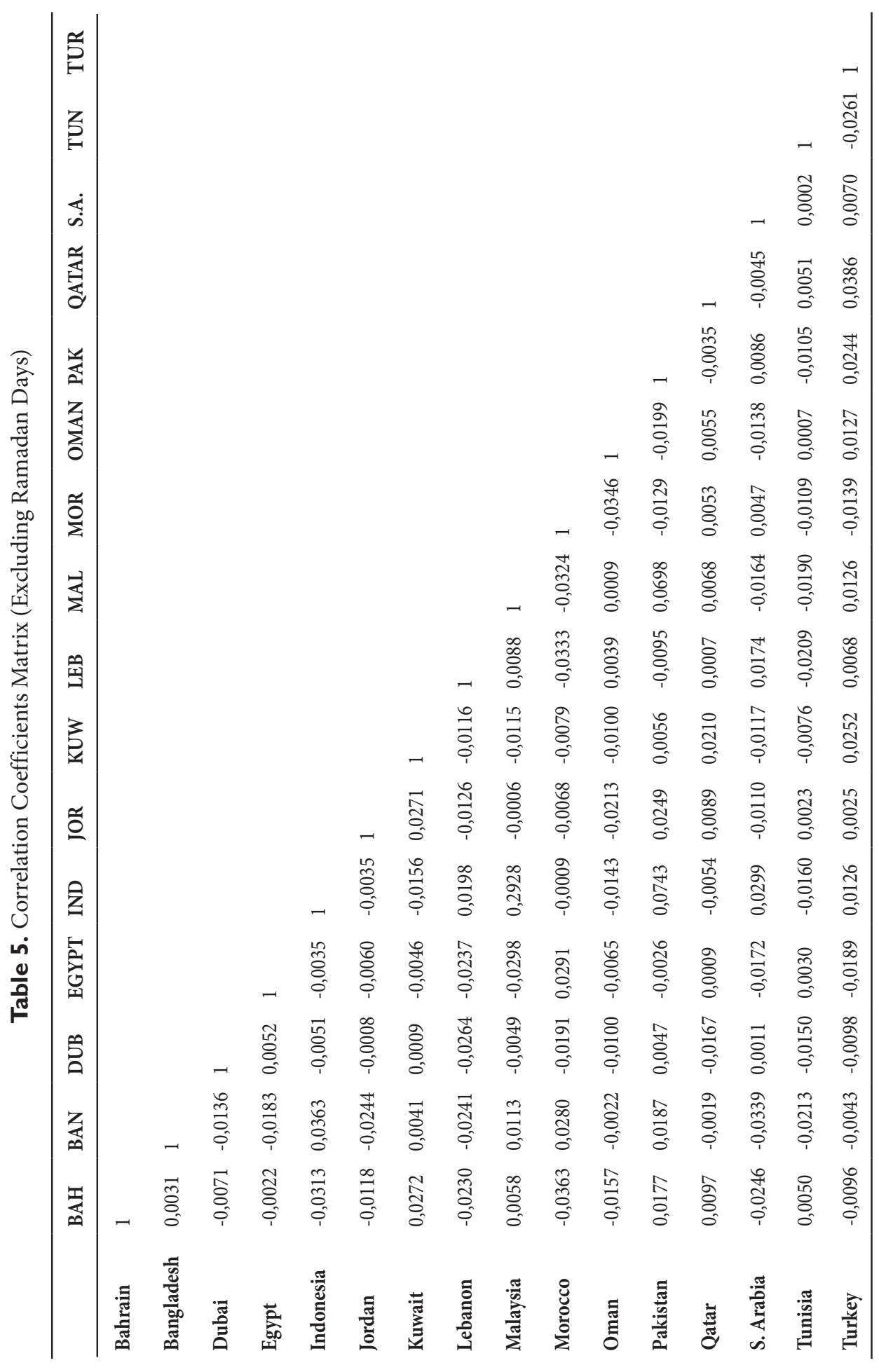




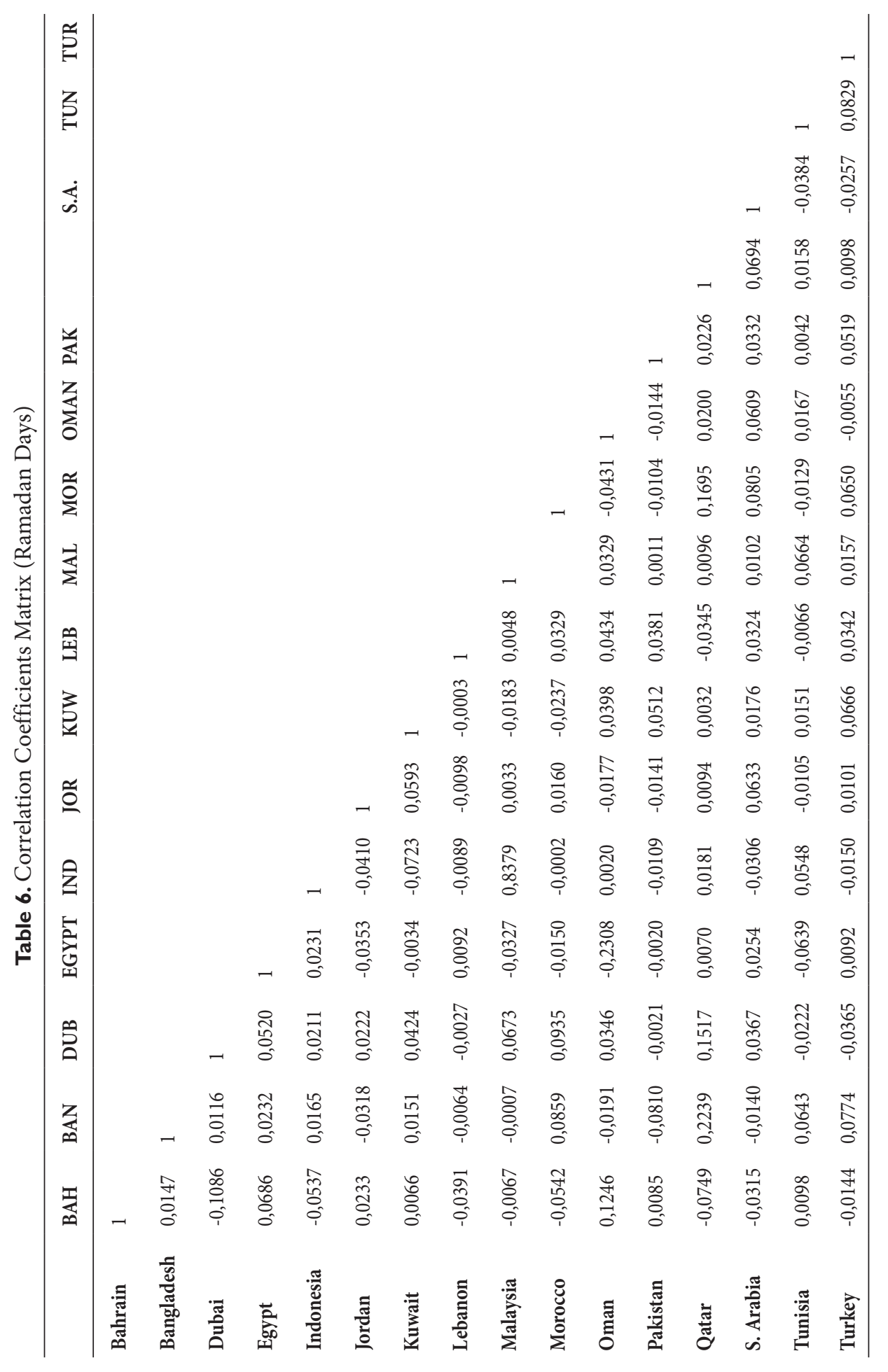


Table 7 displays the regression analysis of the Ramadan effect on stock markets. According to the results, Ramadan's effect on the Bahrain Stock Exchange, Bursa Malaysia, and Casablanca Stock Exchange are negative but statistically insignificant. This shows that Malaysian society is a devoted Islamic society and members of Malaysian society are less actively involved in corporeal pursuits and spend increasingly more time in prayers during this holy month. Malaysian society might be called closer to Islamic practices (Akhter, et. al, 2015). The same might apply to the Moroccan society as well. However, negative results found for Bahrain might, however, reflect the country's religious and cultural differences. Whereas the other countries included in this study are mostly Sunni, Bahrain's population is mostly Shia. Ramadan is important in Bahrain, but Shias also focus on the rituals of grieving and martyrdom associated with the death of Ali ibn Abi Talib and the loss of his sons Hussein and Hassan. Due to these events, a less positive social mood might be exhibited (Al-Hajieh, 2011). Among the 16 countries studied, 13 Muslim financial markets exhibit positive returns during Ramadan. This finding might be attributed to the generally positive investor mood or sentiment. The Dubai Financial Market, Amman Stock Exchange, and Tunis Stock Exchange show statistically significant differences between Ramadan and non-Ramadan periods at $10 \%$. The Karachi Stock Exchange is statistically significant at 1\%. Therefore, it can be concluded that Ramadan exerts an overall, direct positive effect on stock exchanges of Muslim countries.

Table 7. Regression Results of Ramadan Effect

\begin{tabular}{ccccc}
\hline Bahrain Stock Exchange & Coef & $-0,00022$ & Bursa Malaysia & $-0,00012$ \\
& $t$-stat & $(-0,62749)$ & & $(-0,21885)$ \\
Dhaka Stock Exchange & Coef & 0,00028 & Casablanca Stock Exchange & $-0,00047$ \\
& $t$-stat & $(0,4184)$ & & $(-1,01749)$ \\
& Coef & 0,00213 & Muscat Securities Market & 0,00059 \\
Dubai Financial Market & $t$-stat & $(1,7677)$ & & $(1,0761)$ \\
& Coef & 0,00053 & Karachi Stock Exchange & 0,00163 \\
Egyptian Exchange & t-stat & $(0,7532)$ & & $(2,60881)$ \\
\multirow{2}{*}{ Jakarta Stock Exchange } & Coef & 0,00085 & Qatar Stock Exchange & 0,000426 \\
& $t$-stat & $(1,35828)$ & & $(0,3215)$ \\
Amman Stock Exchange* & Coef & 0,00074 & Saudi Stock Exchange & 0,00002 \\
& $t$-stat & $(1,72616)$ & & $(0,02802)$ \\
Kuwait Stock Exchange & Coef & 0,000207 & Tunis Stock Exchange & 0,00049 \\
& $t$-stat & $(0,42653)$ & & $(1,78424)$ \\
Beirut Stock Exchange & Coef & 0,00028 & Borsa Istanbul & 0,00115 \\
& $t$-stat & $(0,46143)$ & & $(1,0217)$ \\
\hline
\end{tabular}

Significance Level: ${ }^{\star}$ indicates $10 \%,{ }^{* *}$ indicates $5 \%,{ }^{* *}$ indicates $1 \%$

Table 8 shows the Ramadan effect divided into the three periods as discussed earlier. According to these results, for the first 10 days, the Ramadan effect is negative for Bahrain, Bangladesh, Egypt, Indonesia, Jordan, Kuwait, Lebanon, Malaysia, Morocco, Oman, Qatar, and Saudi Arabia. These results are consistent with our argument for the first days of Ramadan being 
the hardest for adherents because the need to adjust to fasting during the earlier days might overshadow the positive emotions aroused by the holy period. In contrast, during this first period, only the Turkish stock market shows positive returns, which is statistically significant at $10 \%$. Results for the last 10 days of Ramadan are positive for all countries apart from Malaysia. The findings for the stock markets of Bangladesh and Tunisia are statistically significant at $10 \%$; findings for Dubai, Egypt, Jordan, and Oman are statistically significant at 5\% and results for Pakistan's stock market are statistically significant at $1 \%$, so these results are also consistent with our assertion. The last 10 days of Ramadan are the most blessed part, as they include Laylat Al-Qadar and the period when the Quran being first revealed to Prophet Mohammad. In addition, the third period is also leads to Eid-ul-Fitr. During this time, people purchase gifts, clothes, and food commodities for the feast. It is the time to celebrate the completion of a month of blessing with family and friends. For the second period of Ramadan, the findings for the stock markets of Malaysia and Jordan are both positive and statistically significant at $10 \%$. Interestingly, returns on the Bursa Malaysia are negative for both the first and last 10 days of Ramadan; however, its returns are both positive and statistically significant for the 10 days in the middle of Ramadan.

Table 8. Regression Results of Ramadan 1-10, Ramadan 11-20, Ramadan 21-30

\begin{tabular}{|c|c|c|c|c|}
\hline Stock Markets & & $\begin{array}{c}\text { RAMADAN } \\
1 \_10\end{array}$ & RAMADAN 11_20 & $\begin{array}{c}\text { RAMADAN } \\
21 \_30\end{array}$ \\
\hline \multirow{2}{*}{ Bahrain Stock Exchange } & Coef & $-0,00069$ & $-0,000088$ & 0,0001 \\
\hline & $t$-stat & $(-1,17823)$ & $(-0,14847)$ & $(0,18569)$ \\
\hline \multirow{2}{*}{ Dhaka Stock Exchange } & Coef & $-0,00028$ & $-0,00084$ & $0,001999^{*}$ \\
\hline & $t$-stat & $(-0,24996)$ & $(-0,73677)$ & $(1,73479)$ \\
\hline \multirow{2}{*}{ Dubai Financial Market } & Coef & 0,00101 & 0,00129 & $0,00419^{* *}$ \\
\hline & $t$-stat & $(0,50441)$ & $(0,64031)$ & $(2,02931)$ \\
\hline \multirow{2}{*}{ Egyptian Exchange } & Coef & $-0,00144$ & 0,00046 & $0,00259^{* *}$ \\
\hline & t-stat & $(-1,21384)$ & $(0,38804)$ & $(2,17554)$ \\
\hline \multirow{2}{*}{ Jakarta Stock Exchange } & Coef & $-0,00061$ & $0,00256^{* *}$ & 0,00066 \\
\hline & $t$-stat & $(-0,58196)$ & $(2,40188)$ & $(0,61976)$ \\
\hline \multirow{2}{*}{ Amman Stock Exchange } & Coef & $-0,00056$ & $0,0012^{\star}$ & $0,00168^{\star *}$ \\
\hline & t-stat & $(-0,78815)$ & $(1,66659)$ & $(2,25308)$ \\
\hline \multirow{2}{*}{ Kuwait Stock Exchange } & Coef & $-0,0001$ & $-0,00005$ & 0,00073 \\
\hline & $t$-stat & $(-0,12461)$ & $(-0,05967)$ & $(0,92018)$ \\
\hline \multirow{2}{*}{ Beirut Stock Exchange } & Coef & $-0,00087$ & 0,00105 & 0,0007 \\
\hline & $t$-stat & $(-0,8904)$ & $(1,06652)$ & $(0,70932)$ \\
\hline
\end{tabular}




\begin{tabular}{|c|c|c|c|c|}
\hline Bursa Malaysia & $\begin{array}{l}\text { Coef } \\
\text { t-stat }\end{array}$ & $\begin{array}{l}-0,00102 \\
(-1,1036)\end{array}$ & $\begin{array}{l}0,00157^{\star} \\
(1,66816)\end{array}$ & $\begin{array}{c}-0,00088 \\
(-0,94261)\end{array}$ \\
\hline \multirow{2}{*}{ Casablanca Stock Exchange } & Coef & $-0,00108$ & $-0,00051$ & 0,00019 \\
\hline & t-stat & $(-1,40582)$ & $(-0,65176)$ & $(0,24607)$ \\
\hline \multirow{2}{*}{ Muscat Securities Market } & Coef & $-0,00095$ & 0,00066 & $0,00206^{* *}$ \\
\hline & $t$-stat & $(-1,03414)$ & $(0,71925)$ & $(2,23691)$ \\
\hline \multirow{2}{*}{ Karachi Stock Exchange } & Coef & 0,0005 & 0,00125 & $0,003175^{\star * *}$ \\
\hline & t-stat & $(0,47867)$ & $(1,17853)$ & $(-3,00809)$ \\
\hline \multirow{2}{*}{ Qatar Stock Exchange } & Coef & $-0,00102$ & 0,00155 & 0,00002 \\
\hline & $t$-stat & $(-0,48938)$ & $(0,71372)$ & $(0,01092)$ \\
\hline \multirow{2}{*}{ Saudi Stock Exchange } & Coef & $-0,00168$ & $-0,00031$ & 0,00036 \\
\hline & t-stat & $(-1,28506)$ & $(-0,23494)$ & $(-1,49777)$ \\
\hline \multirow{2}{*}{ Tunis Stock Exchange } & Coef & 0,000464 & 0,000173 & $0,000839^{\star}$ \\
\hline & t-stat & $(-1,01824)$ & $(0,37293)$ & $(-1,79813)$ \\
\hline \multirow{2}{*}{ Borsa Istanbul } & Coef & $0,00343^{*}$ & $-0,00006$ & 0,00001 \\
\hline & t-stat & $(1,80792)$ & $(-0,02895)$ & $(0,00625)$ \\
\hline
\end{tabular}

Significance Level: ${ }^{\star}$ indicates $10 \%,{ }^{*}$ indicates $5 \%{ }^{\star * \star}$ indicates $1 \%$.

\section{Conclusion}

The month of Ramadan is one the most renowned religious rituals in the world for more than 1.5 billion Muslims. Muslims alter many aspects of their behavior during the month of Ramadan. Their working patterns change and they are focused more on praying, reciting the Quran, and giving alms from their previous year's earnings. These practices bring about greater solidarity and collaboration between Muslims. This study analyzes the effect of Ramadan on the stock exchanges of 16 Muslim countries.

According to the results of the regression analysis, the Ramadan effect is negative but statistically insignificant for the Bahrain Stock Exchange, Bursa Malaysia, and Casablanca Stock Exchange. Among the 16 countries studied, 13 Muslim financial markets have positive returns during Ramadan, which can be attributed to the generally positive investor mood or emotions. The differences in returns on the Dubai Financial Market, Amman Stock Exchange, and Tunis Stock Exchange are statistically significant at $10 \%$, while it is statistically significant for the Karachi Stock Exchange at 1\%. It can, therefore, be concluded that Ramadan exerts a direct positive effect on stock exchanges in the countries studied. These results are consistent with the previous studies of (Al-Ississ, 2010; Al-Hajieh, Redhead, and Rodgers, 2011; Białkowski, Etebari \& Wisniewski, 2012).

Furthermore, this study splits the Muslim holy days into 3 periods, where the first period includes the first 10 days of Ramadan, second period covers the next 10 days of the Ramadan month, and 
the final period comprises the last 10 days. According to results, while the first 10 days witness the lowest performance, the last 10 days experience the highest performance. These results are also coherent with the study of Al-Ississ (2010). This study can be extended by applying volatility analysis of stock markets in order compare with Ramadan and non-Ramadan days. Also, because

of missing data of Iran during the study, it couldn't consider in this study, however, because of the importance place of Iran within Muslim society, Tehran stock exchange should be considered into the study.

\section{References}

Akhter, A., Sandhu, A, Butt S. 2015. Islamic Calendar Effect on Market Risk and Return. Evidence from Islamic countries. Journal of Business and Finance Affairs, 4:140. doi:

$10.4172 / 2167$ 0234.1000140 .

Alatiyat, M., A. 2014. Ramadan Effect on UAE Stock Market. Retrieved December 15, 2015 From https:// www.researchgate.net/publication/263090131_Ramadan_Effect_On_UAE_Stock_Market_-_ Banks_Sector.

Al-Hajieh, H., Redhead, K, Rodgers, T. (2011). Investor Sentiment and Calendar Anomaly Effects: A Case Study of the Impact of Ramadan on Islamic Middle Eastern Markets. Research in International Business and Finance 25, 345-356.

Al-Ississ, M. 2010. The Impact of Religious Experience on Financial Markets. Retrieved November 30, 2015 From https://www.researchgate.net/profile/Mohamad_Al-Ississ/publications.

Al-Ississ, M. 2015. The Holy Day Effect. Retrieved January 2, 2016 From http://www1.aucegypt.edu/faculty/ alississ/pdf/The\%20Holy\%20Day\%20Effect\%20March\%202015.pdf.

Alrashidi, F., Ahmed, M, Beneid, F. 2014. The Calendar Impact and Trading Behavior: an Empirical Evidence From Around the Globe. International Business \& Economics Research Journal 13(5), 1025-1032.

Beit-Hallalmi, B, Argyle, M. 1997. The Psychology of Religious Behavior. Belief and Experience. Routledge, London.

Białkowski, J., Etebari, A, Wisniewski, T. P. 2012. Fast Profits: Investor Sentiment and Stock Returns During Ramadan. Journal of Banking \& Finance 36, 835-845.

Create Calendar. Retrieved November 20, 2015. from http://www.timeanddate.com/calendar/custom. html? year $=2004 \&$ country $=74 \&$ cols $=1 \&$ typ $=0 \&$ display $=1 \& \mathrm{df}=1$.

Countries in the world (Ranked by 2014 population), Retrieved December 10, 2015. From http://www. worldometers.info/world-population/population-by-country/.

Dini Günler. Retrieved November 10, 2015. From http://takvim.ihya.org/1990-yili-dini-gunler-takvimi.html.

Frieder, L, Subrahmanyam, A. 2004. Nonsecular Regularities in Returns and Volume. Financial Analysts Journal 60:4, 29-34.

Husain, F. 1998. A Seasonality in the Pakistani Equity Market: The Ramadhan Effect. The Pakistan Development Review 37:1, 77-81.

Iqbal, M. S., Kouser, R, Azeem, M. (2013). Conventional and Islamic Anomalies in Karachi Stock Exchange. Retrieved December 02, 2015, From http://www.sci-int.com/pdf/ 132487349256-999-1007_ Rehana\%20kausar-Manuscript\%20BZ\%20Uni.pdf.

Nofsinger, J. R. (2002). Do Optimists Make the Best Investors? Corporate Finance Review 6:4, 11-17. 
Population of Muslim Countries. Retrieved December 28, 2015. From https://www.cia.gov/library/ publications/the-world-factbook/fields/2122.html.

Ramadan's Calendar. Retrieved November 15, 2015. From http://www.dnzh.com/webservices/ ramadancalendar.aspx.

Ramadan in Dubai. Retrieved November 10, 2015. From http://www.dubaifaqs.com/ramadan-in-dubai.php.

Ramezani, A., Pourahajan, A, Mardani, H. (2013). Studying Impact of Ramadan on Stock Exchange Index: Case of Iran. World of Sciences Journal 1(12), 46-54.

Saudi Ummul-Qura Calendar. Retrieved November 17, 2015. From http://www.moonsighting.com/actualsaudi-dates.pdf.

Seyyed, F. J., Abraham, A, Al-Hajji, M. 2005. Seasonality in Stock Returns and Volatility: The Ramadan Effect. Research in International Business and Finance 19, 374-383.

Shah, A. R, Ahmed, S. N. 2014. The Ramadan Effect on Stock Market. European Academic Research 1:11, 4712-4720.

Surah Al-Qadr (97:3). Retrieved December 25, 2015. From http://quran.com/97.

Weber, M, 1930. The Protestant Ethic and Spirit of Capitalism (Kalberg, S, Trans.). London: Fitzroy Dearborn, 200.

\section{APPENDIX B: FIGURES}

Figure I: Price Index of 16 Countries
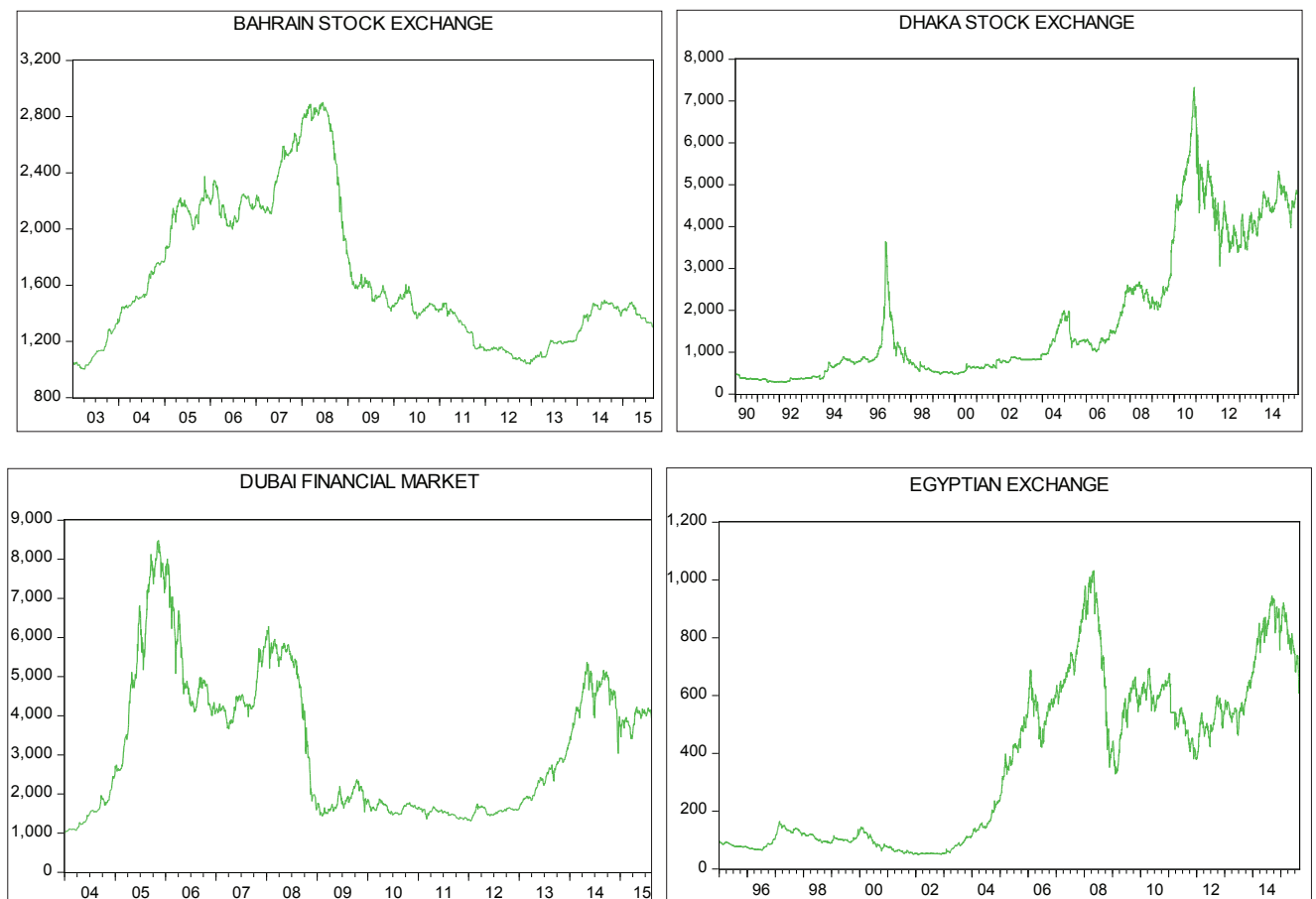

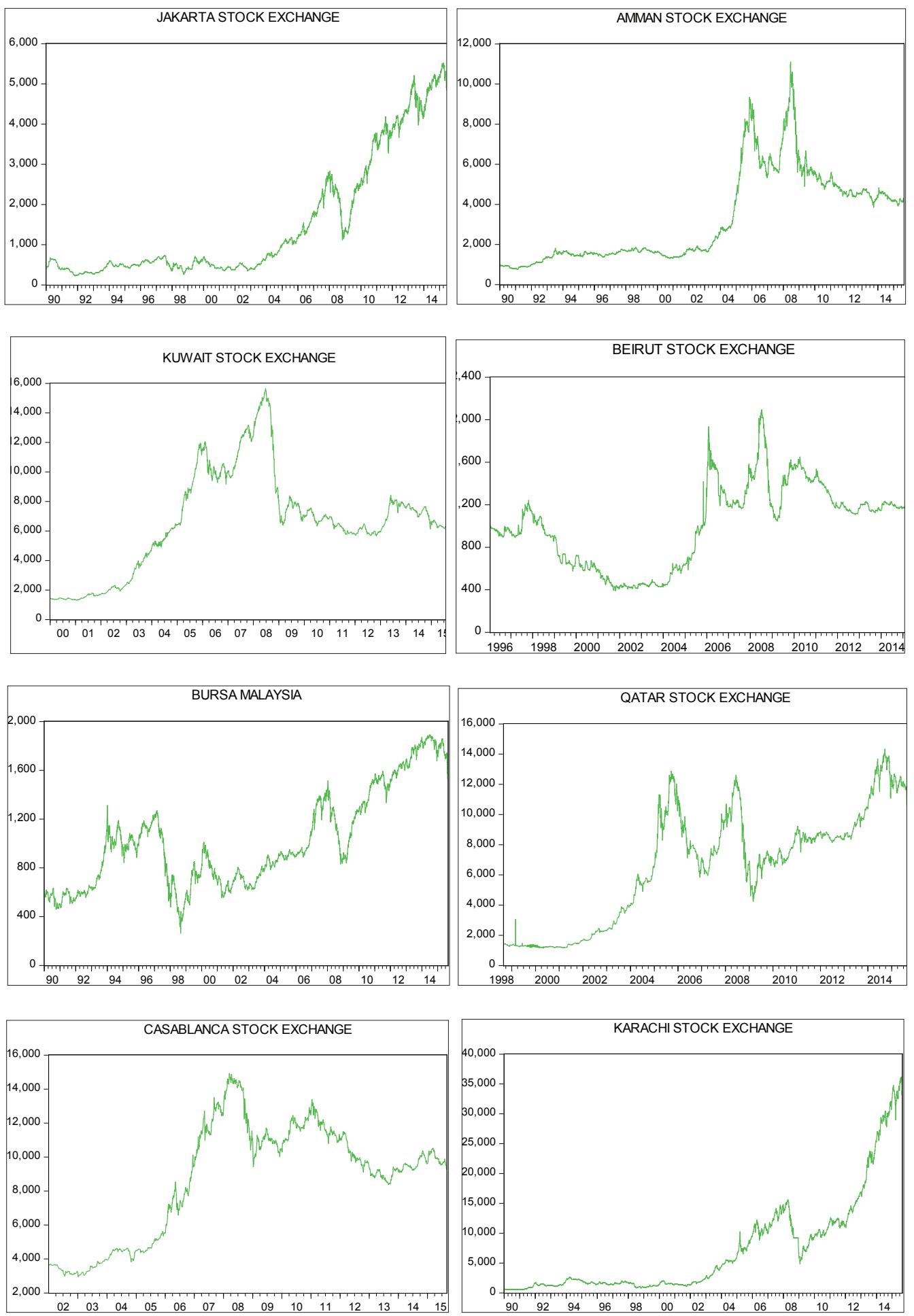

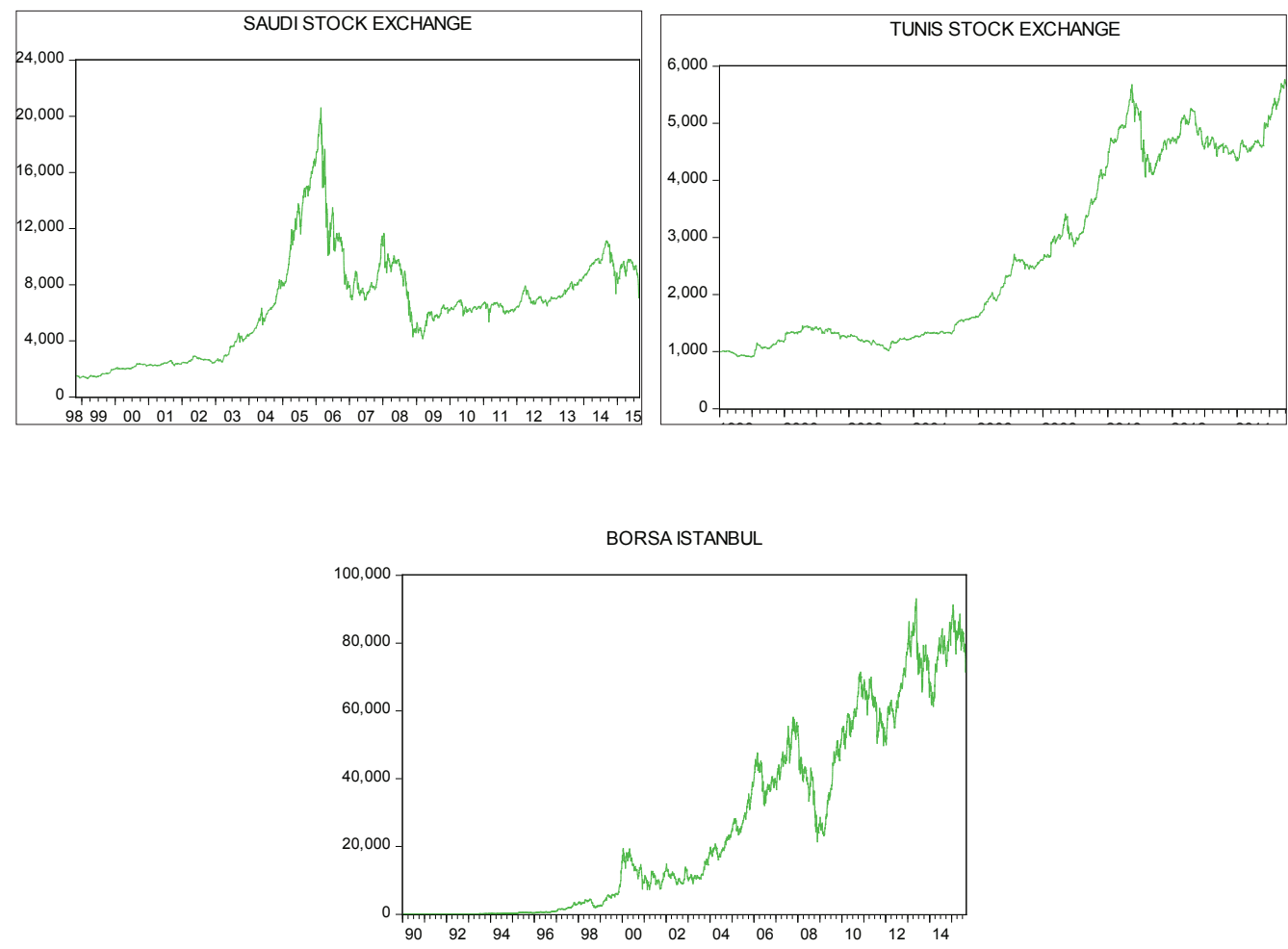

Figure 2: Daily Stock Returns (Excluding Ramadan Days)
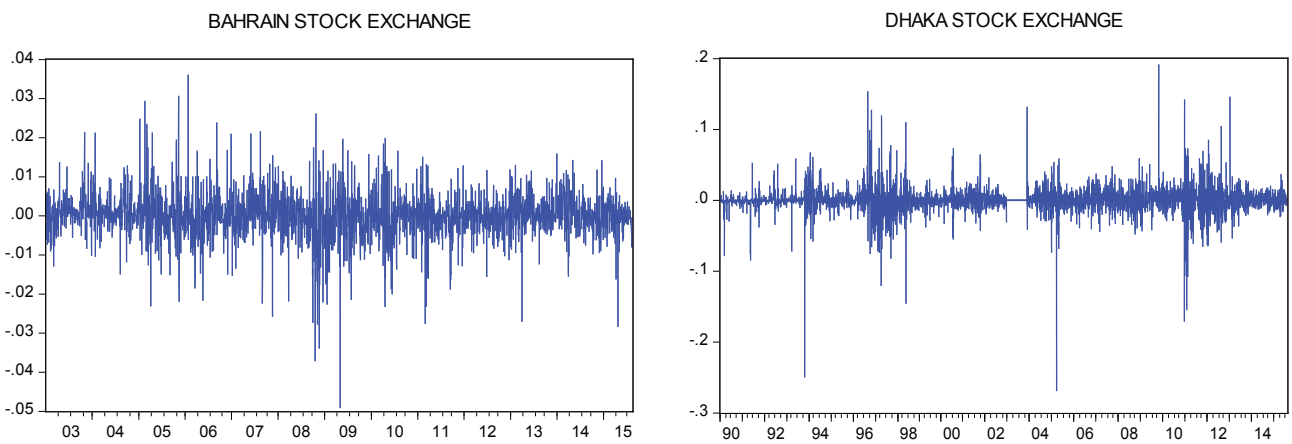

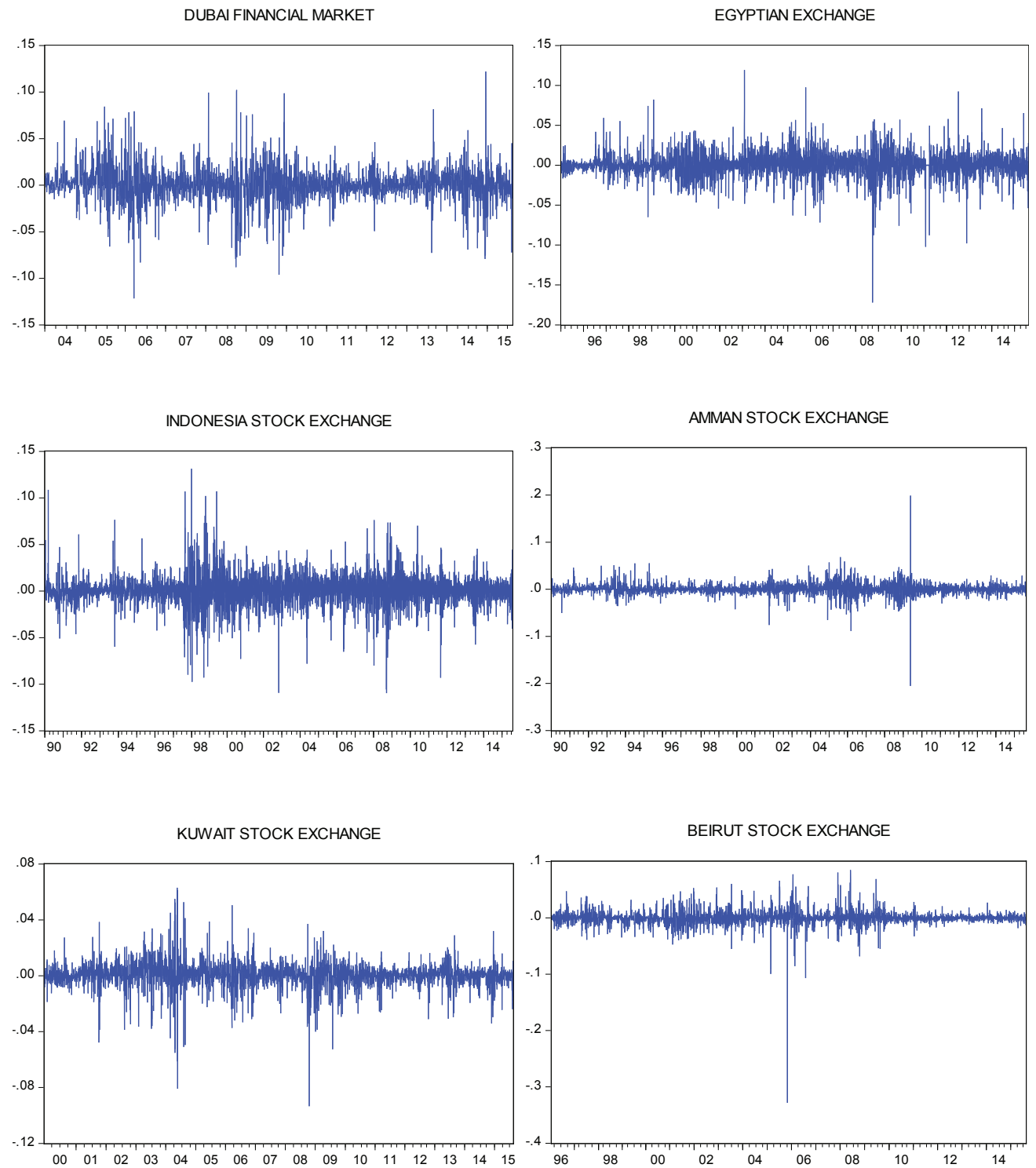
BURSA MALAYSIA

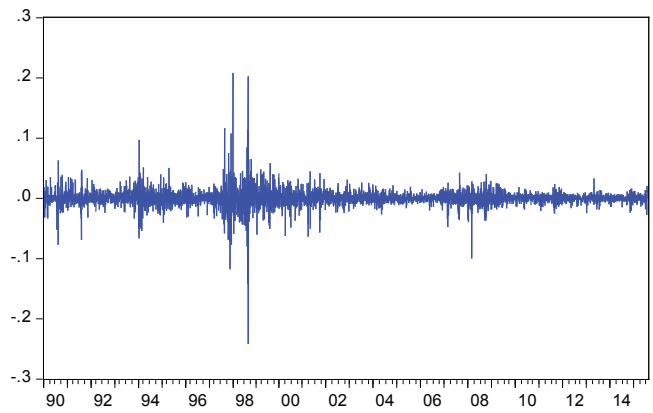

MUSCAT SECURITIES MARKET

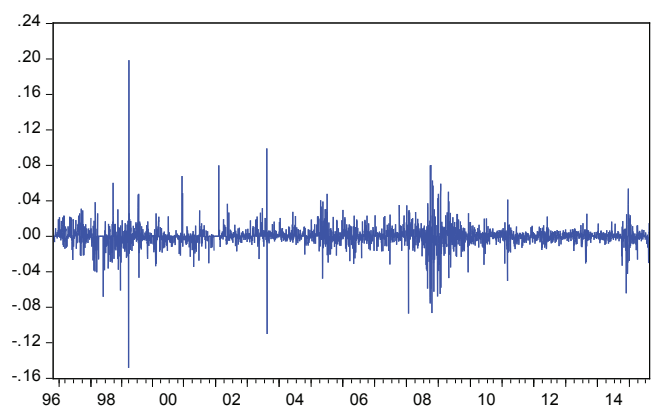

QATAR STOCK EXCHANGE

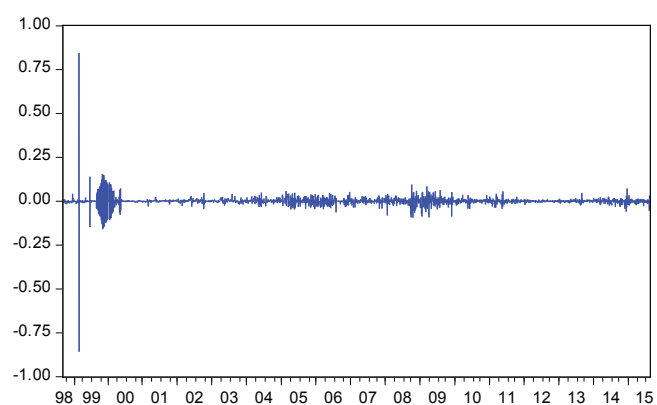

CASABLANCA STOCK EXCHANGE

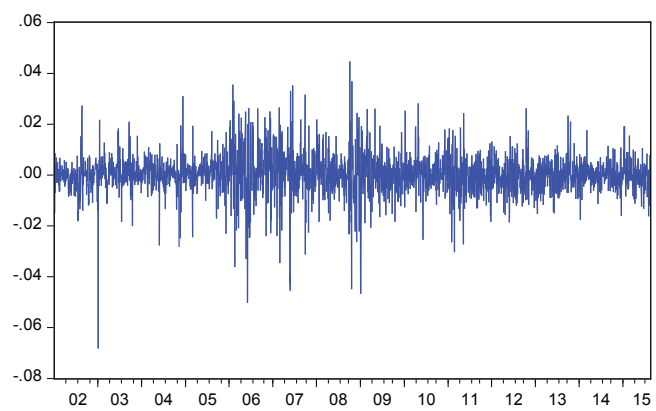

KARACHI STOCK EXCHANGE

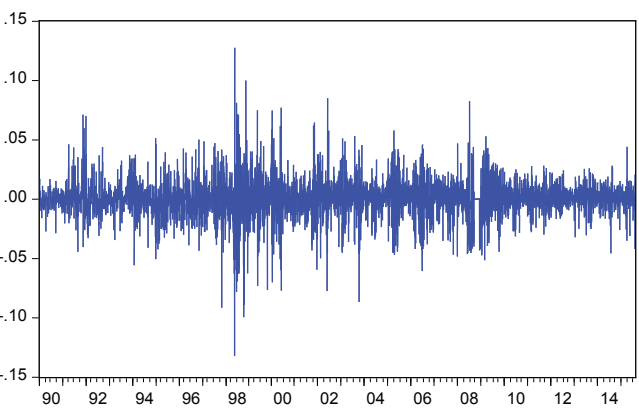

SAUDISTOCK EXCHANGE

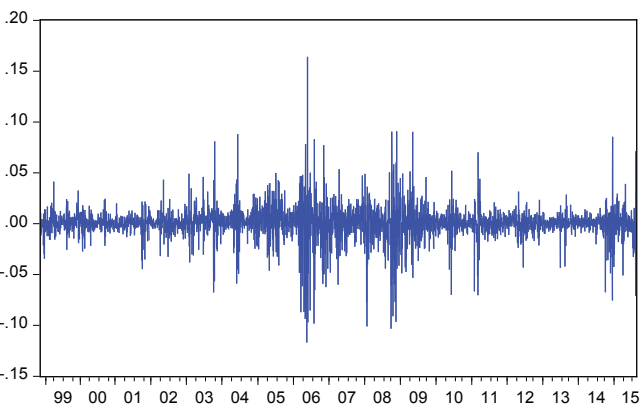



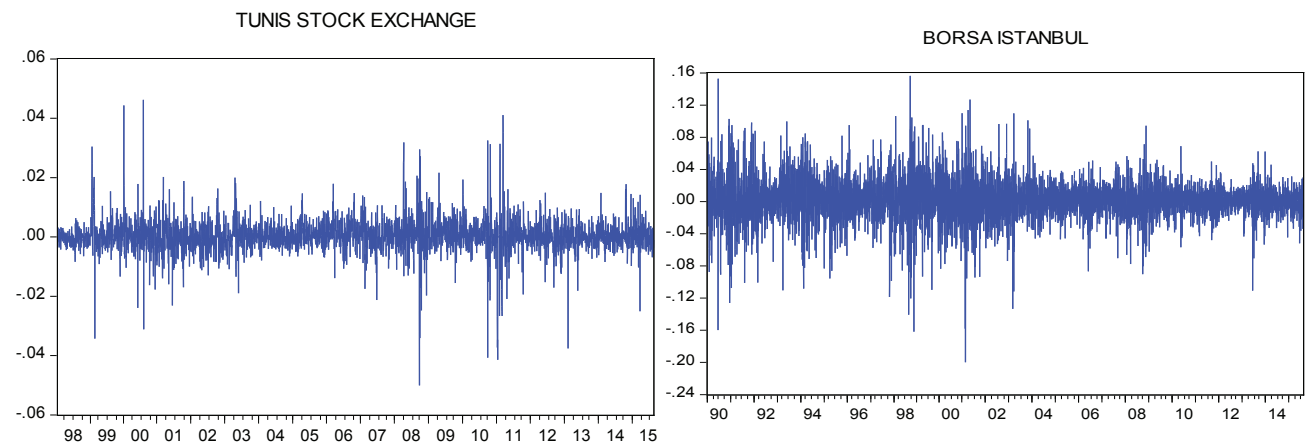

Figure 3: Stock Returns (only Ramadan Days)
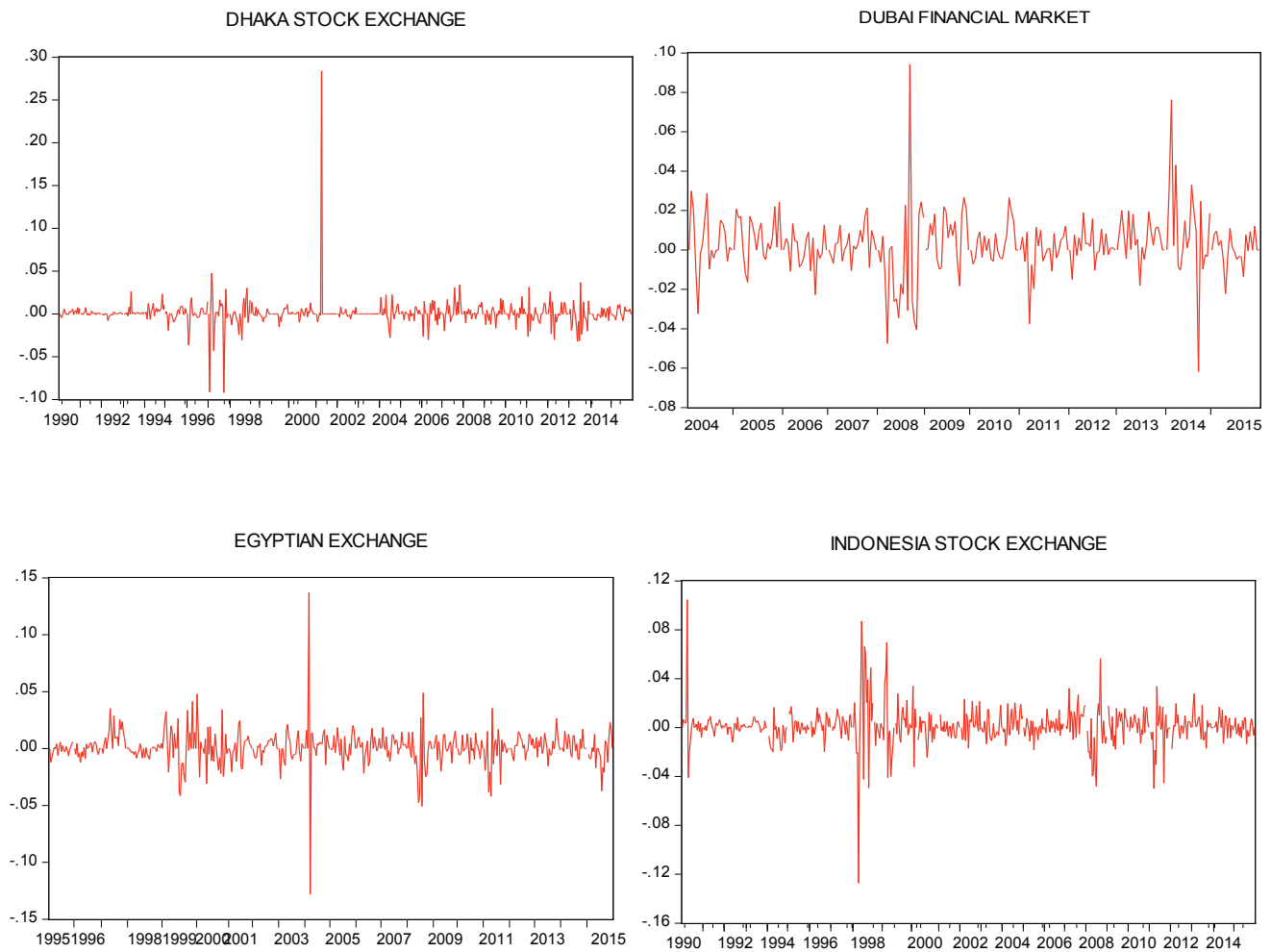

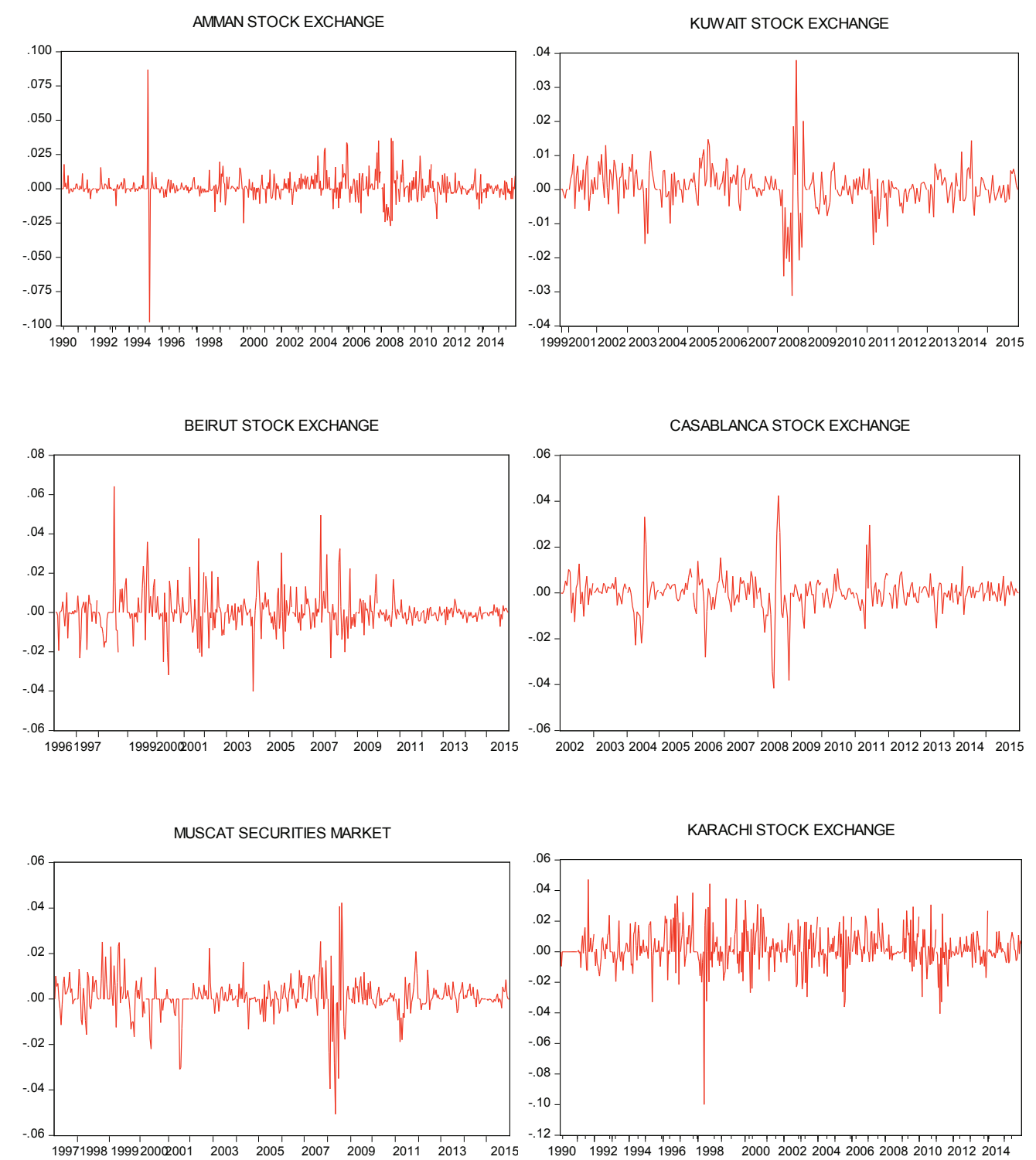
